\title{
EDITORIAL
}

\section{REINICIANDO ATUÁRIA NA FEA/USP}

Que o homem faz contas há milhares de anos, não restam dúvidas; e que se dedica a jogos de azar por esse tempo todo, também năo. Mas, dentro dessa evolução, até chegar à moderna contabilidade internacional e aos sofisticados cálculos probabilísticos da ciência atuarial e dos riscos. não deixa de ser curioso que Atuária e Contabilidade tenham tido tantos pontos em comum. Apenas, a seguir, alguns poucos exemplos.

Em Desafio aos Deuses. P. L. Bernstein salienta que o livro Liber abaci, de Fibonacci, em 1202. "foi o primeiro passo espetacular na transformação da medição no fator-chave do controle sobre o risco" (16a. ed., p. 28). Fibonacci, nesse mesmo livro, mostra ainda um pouco do funcionamento da Contabilidade e alguns de seus aspectos primários. (Fora suas incursões no mundo aplicado da matemática, como a que resultou na 'série Fibonacci'.)

Salienta também Bernstein que Luca Paccioli, quase 3 séculos depois, ao escrever Summa de arithmetic, geometria et proportionalitá. apresenta em um dos seus capítulos "uma das contribuiçōes mais notáveis... a contabilidade por partidas dobradas": embora não inventada por ele, deu-Ihe, nesse livro, "o mais extenso tratamento até entāo" (p. 42). E nesse mesmo livro apresenta Paccioli um problema que ficou conhecido como o "problema dos pontos'; segundo Bernstein, por causa dele " $A$ resoluçāo de como dividir as apostas em um jogo interrompido marcou o inicio da análise sistemática da probabilidade - a medição de nossa confiança em que algo vai acontecer. Ele nos leva ao limiar da quantificação do risco." (p.43). (Apenas por curiosidade citamos que Paccioli escreveu também Divine proportione, que tanto encantou e inspirou seu dileto amigo Leonardo da Vinci e ganhou dele diversos desenhos complexos; ambos dominaram e aplicaram a 'Razão de ouro' como ninguém, na teoria e na prática.)

Mas, continuando nesses exemplos de vínculo histórico entre Atuária e Contabilidade e saltando alguns anos, temos, em 1946, a criação, pelo governo federal, em nível superior. do Curso de Contabilidade e Atuária. Nascem umbilicalmente ligados. São um único curso. Mesmo a profissão de Atuária não tendo ainda nenhum reconhecimento legal.

E a FEA/USP (à época Faculdade de Ciências Econômicas e Administrativas), ao ser criada nesse mesmo ano de 1946, inicia suas atividades com dois cursos: de um lado o de Ciências Econômicas; e do outro, o de Contabilidade e Atuária. E assim estiveram Atuária e Contabilidade vinculadas até o início da década de 60 na FEA (e, em algumas escolas, por mais tempo ainda). quando passaram a ser dois cursos autônomos. com a criaçāo, ao mesmo tempo. dos cursos de Administração de Empresas e Administração Pública, ficando então nossa Faculdade com cinco cursos.

A Profissão de Atuário acabou sendo criada no País através do Decreto-lei n² 806 de 4 de setembro de 1969, com sua regulamentação ocorrendo com o decreto n 66.408, de abril de 1970. Mas, apesar de cursos autônomos, o Departamento da FEA que os oferecia chamava-se, e ainda se chama Departamento de Contabilidade e Atuária, mantendo a vinculação histórica.

Mas, infelizmente, por falta de demanda, os cursos de Atuária e Administração Pública tiveram que deixar de ser ofertados. Várias tentativas foram feitas para a sua reativação. Uma alternativa inicial foi a de retomar o curso de Atuária, oferecendo-o apenas para alunos que já tivessem um curso de graduação concluído, pois se julgava que, sendo mais maduros, estariam mais bem preparados e firmes na escolha da profissão. Mas esse projeto, aprovado pelo Conselho do Departamento de Contabilidade e Atuária, não foi adiante por não ter sido aprovado por outros órgãos da Universidade em função de contar com o patrocínio de entidades empresariais. O Departamento continuou tentando retornar o curso, tendo apresentado diversos projetos ao longo do tempo. Enquanto isso, principalmente com a deterioração da previdência básica oficial, o mercado de seguros, de capitalização, de previdência aberta e fechada cresciam, demandando cada vez mais o concurso de profissionais especializados nesses ramos de atividade. A criaçăo de novos produtos não vinculados ao ramo vida, a globalizaçāo. o aumento da violência e da insegurança e o vertiginoso crescimento dos riscos, bem como o acirramento da concorrência entre as entidades securitárias, tudo isso fez crescer o segmento de seguros. O mercado demandava profissionais especializados em avaliação desses tipos de riscos e, assim, novos cursos de graduação em Atuária foram criados, principalmente em São Paulo e os que já existiam expandiram o número de vagas.

Finalmente, após exaustivos esforços do Departamento de Contabilidade e Atuária, a Universidade de São Paulo autorizou o reinicio de seu curso de graduaçāo em Atuária, justamente neste ano de 2006, em que se comemoram os 60 anos da FEA/USP. O curso terá a duração de 4 anos e com um perfil diferenciado: além de formar o especialista no cálculo dos riscos ligados ao "passivo" atuarial (riscos, obrigações das entidades securitárias e previdenciárias). irá formar também o lado profissional ligado à gestão dos "ativos", ou seja, com todos os conhecimentos básicos de finanças, economia e contabilidade necessários à boa gestão dos recursos arrecadados por essas entidades de forma a permitir o cumprimento daquelas obrigaçōes.

A volta do curso de graduação em Atuária é uma grande vitória do Departamento de Contabilidade e Atuária da FEA/USP (note-se que Contabilidade e Atuária estāo de novo juntas nessa nossa Escola) e deve ser creditada aos ilustres professores Eliseu Martins, Geraldo Barbieri, Iran Siqueira Lima, Luiz Joāo Corrar e Reinaldo Guerreiro, bem como à então Diretora da FEA Maria Tereza Leme Fleury, que concorreram com sua iniciativa e seus esforços ao longo desses últimos 16 anos para que esse objetivo fosse atingido.

Iran Siqueira Lima Professor Doutor do Depto. de Contabilidade e Atuária da FEA/USP 